\title{
PENDIDIKAN ISLAM DI MADRASAH: Suatu Kajian Permasalahan dan Solusi Pendidikan Madrasah dalam Perspektif Filsafat Pendidikan Islam
}

\author{
Ilham \\ Institut Agama Islam (IAI) Muhammadiyah Bima \\ Email: ilhamham903@gmail.com
}

\begin{abstract}
Abstrak:
Madrasah sebagai basis pendidikan Islam sekarang ini dihadapkan pada persoalan-persoalan yang cukup kompleks, yakni persoalan manajemen, reformasi dan globalisasi menuju masyarakat Indonesia baru. Tantangan yang dihadapi sekarang adalah bagaimana upaya untuk membangun paradigma baru pendidikan Islam, visi, misi, dan tujuan, yang didukung dengan sistem kurikulum, manajemen dan organisasi, metode pembelajaran untuk dapat mempersiapkan manusia yang berkualitas, bermoral tinggi dalam menghadapi perubahan masyarakat global yang begitu cepat, sehingga produk pendidikan Islam tidak hanya melayani dunia modern, tetapi mempunyai pasar baru atau mampu bersaing secara kompetetif dan proaktif dalam dunia masyarakat modern. Oleh karena itu, posisi madrasah dalam menyelenggarakan pendidikan Islam meski melakukan tansformasi diri dalam membangun sitem pendidikanan antara lain; pertama, Membangun sistem pendidikan Islam yang mampu mengembangkan sumber daya manusia yang berkualitas agar mampu mengantisipasi kemajuan IPTEK untuk menghadapi tantangan dunia global menuju masyarakat Indonesia baru yang dilandasi dengan nilai-nilai ilahiyah, kemanusia (insaniyah), dan masyarakat, serta budaya. Kedua, Menata manajemen pendidikan Islam dengan berorientasi pada manajemen berbasis sekolah agar mampu menyerap aspirasi masyarakat, dapat mendayagunakan potensi masyarakat, dan daerah (otonomi daerah) dalam rangka penyelenggaraan pendidikan Islam yang berkualitas. Ketiga, Meningkatkan demokratisasi penyelenggaraan madrasah secara berkelanjutan dalam upaya memenuhi kebutuhan masyarakat agar dapat menggali serta mendayagunakan potensi masyarakat.
\end{abstract}

Kata Kunci: Madrasah, Pendidikan Islam, Permaslahan, Solusi

\section{Pendahuluan}

$\mathrm{K}$

elahiran pendidikan Islam di Indonesia yang berawal dari penyelengaraan pondok pesantren, tujuan utamanya adalah memberikan dan al-Hadits dalam kehidupan umat Islam. ${ }^{1}$ Tentu saja tujuannya adalah mencitacitakan terbentuknya Insan Kamil atau muslim paripurna, yang secara eksplisit mencerminkan ciri-ciri kualitas manusia Indonesia seutuhnya. Perkembangan

${ }^{1}$ Zuhairini, Dkk., Sejarah Pendidikan Islam, (Cet. 8, Jakarta: PT. Bumi Aksara Bekerjasama Dengan Direktorat Jenderal Pembinaan Kelembagaan Agama Islam Departemen Agama; 2006), 219 
selanjutnya, pendidikan Islam yang berwujud dalam bentuk lembaga pendidikan mengalami pasang surut sesuai dengan tingkat kemajuan masyarakat pada umumnya. Mulai dari pembelajaran tradisional (pondok pesantren) sampai kepada madrasah seperti dikenal sekarang dan seterusnya perkembangan pendidikan Islam banyak menghadapi masalah kelembagaan baik dari segi fungsi edukasi maupun dari segi model pengelolaannya, sehingga terlihat madrasah tidak terselenggara dengan baik bahkan tidak responsif terhadap tuntutan pada saat ini. ${ }^{2}$

Keadaan ini membuat masyarakat tidak tertarik memasukkan anaknya dalam pendidikan madrasah dan keberadaan madrasah semakin tidak diminati. Usaha peningkatan mutu madrasah adalah merupakan serangkaian kegiatan masyarakat secara terencana terkait dengan usaha menumbuhkembangkan madrasah dalam berbagai aspek dan sebagai pemenuhan kebutuhan masyarakat akan kemajuan pendidikan bagi anak-anaknya. Bila di pandang surut ke belakang, kehadiran madrasah adalah salah satu lembaga pendidikan yang mempunyai program-program pendidikan yang dilaksanakan oleh pemerintah bersama dengan masyarakat yang bertanggung jawab untuk mencerdaskan kehidupan bangsa, yang memiliki visi, misi dan karakteristik yang khas dalam upaya pembangunan dan pembinaan umat. Madrasah menjadi harapan umat Islam selain pendidikan pada pondok pesantren sebagai pusat pembinaan generasi islami.

Namun perkembangan pendidikan madrasah selanjutnya dalam penyelenggaraan kurang kondusif, salah satunya yaitu tidak ada pelibatan penuh yang diberikan kepada masyarakat untuk mengelola pendidikannya, karena adanya kebijakan yang kurang berpihak kepada madrasah sehingga kehadiran madrasah dalam konteks pendidikan masa kini tidak mampu menyesuaikan diri dengan perkembangan zaman, akhirnya pendidikan pada madrasah semakin terpinggirkan. ${ }^{3}$ Kondisi ini berimbas kepada keberadan peserta didik luaran (output) madrasah kurang memberikan jaminan hidup yang lebih baik secara ekonomis. Pada masa orde lama, seluruh kebijakan cenderung terpusat dengan kekuasaan politik yang sangat kuat, dimasa ini bantuan dan subsidi yang sebelumnya madrasah menikmatinya ternyata tidak ada, campur tangan pemerintah kepada madrasah juga tidak nampak, menyebabkan madrasah semakin ketinggalan menurut pandangan masyarakat umum.

Disambung dengan masa orde baru suasana sentralisasi penyelenggaraan semakin meningkat dan lembaga pendidikan menjadi bagian dari birokrasi. Dari sini lembaga pendidikan agama kurang mampu bersaing menjadi bukti lemahnya pembinaan dalam meningkatkan kualitas lembaga penddikan madrasah

${ }^{2}$ A. Malik Fadjar, Visi Pembaharuan Pendidikan Islam, (Jakarta: LP3ES; 1998). h. 78-79

${ }^{3}$ M. Khalid Fathoni, Pendidikan Islam Dalam Paradigma Baru Pendidikan Nasional, (Bogor: Regina; 2005), 74 
(pendidikan Islam). ${ }^{4}$ Hal yang menonjol bagi perkembangannya ialah mengalami penurunan baik dari segi kualitas maupun dari segi kuantitas. Salah satu faktor yang menyebabkannya adalah dengan lahirnya undang-undang pendidikan yang sifatnya setralistik, cenderung mengatur dan melakukan penyeragaman dalam hal struktur sampai masalah yang sifatnya teknis, mengatur kurikulum serta bantuan sarana dan prasarana lainnya. Hal ini tentu saja mempengaruhi kehidupan madrasah khususnya yang berhubungan dengan tingkat partisipasi masyarakat. Era reformasi yang sedang kita jalani, telah membawa perubahan-perubahan yang mendasar dalam berbagai sudut kehidupan manusia, termasuk pelaksanaan pendidikan. Salah satu perubahan mendasar yang sedang digulirkan saat ini adalah manajemen negara, yakni manajemen berbasis pusat menjadi manajemen berbasis daerah. Secara resmi perubahan manajemen ini diwujudkan dalam bentuk Undang-Undang RI No. 22 Tahun 1999 Tentang Pemerintahan Daerah, ${ }^{5}$ yang kemudian diikuti oleh pedoman pelaksanaanya berupa Peraturan Pemerintah RI Nomor 25 Tahun 2000 tentang kewenangan propinsi sebagai daerah otonom. Konsekwensi logis dari undang-undang dan peraturan pemerintah tersebut adalah membawa manajemen pendidikan harus disesuaikan dengan semangat otonomi.

Keinginan pemerintah yang digariskan dalam haluan negara agar pengelolaan pendidikan diarahkan pada desentralisasi, menuntut partispasi stakeholder (pelaku dan pelaksana) madrasah atau pendidikan Islam secara aktif untuk merealisasikan otonomi daerah. ${ }^{6}$ Hal ini memberikan konsep kelanjutan kepada madrasah dalam merumuskan konsep yang lebih strategis baik dari segi model pengelolaan yang berbasis sekolah maupun segi kedudukannya yang sepenuhnya dirancang secara sinergis dan pelibatan semua komponen masyarakat sebagai stakeholder pendidikan untuk menciptakan sekolah mandiri sehingga kualitas madrasah mampu bersaing dengan lembaga pendidikan lainnya. Karena hal itu perlu kesiapan madrasah sebagai wadah dalam pelaksana operasional pendidikan Islam.

Gagasan perbaikan pendidikan yang dituangkan dalam Undang-Undang Sistem Pendidikan Nasional No. 20 Tahun 2003 Bab III Pasal 4 ayat 1,

\footnotetext{
${ }^{4}$ Aulia Reza Bastian, Reformasi Pendidikan: Langkah-Langkah Pembaruan Pendidikan Dalam Rangka Desentralisasi Pendidikan Indonesia, (Yogyakarta: Lappera; 2002), 34

${ }^{5}$ Redaksi Sinar Grafika, Undang-Undang RI Nomor 22 Tahun 1999 Tentang Pemerintahan Daerah, (Jakarta: Sinar Grafika; 1999). h. 7 undang-undang ini menginginkan bahwa pengelolaan pendidikan, baik pendidikan umum maupun pendidikan Islam (madrasah) di otonomkan serta diserahkan kepada daerah untuk mengelola pendidikan yang menjamin mutu pendidikannya, namun posisi pendidikan Islam (madrasah) masih menunai perbincangan, apakah di otonomkan atau tidak.

${ }^{6}$ Dede Rosyada, Paradigma Pendidikan Demokratis: Sebuah Model Pelibatan Masyarakat Dalam Penyelenggaraan Pendidikan, (Cet. III, Jakarta: Kencana Prenada Media Group; 2009), 5

${ }^{7}$ Bahwa pendidikan diselenggarakan secara demokratis dan berkeadilan serta tidak diskrimiatif dengan menjunjung tinggi hak asasi manusia, nilai keagamaan, nilai kultural dan
} 
memperoleh tempat yang sangat ideal bagi madrasah (pendidikan Islam), karena keberadaan madrasah merupakan bagian dari sistem pendidikan nasional yang didalamnya memberikan penguatan pada pengelolaan pendidikan yang demokratis serta mendorong optimalisasi peran serta masyarakat dengan memberikan peluang pada madrasah untuk mengembangkan networking horizontalnya dengan para stakeholder-nya dalam proses perencanaan madrasah, pengembangan kurikulum maupun penetapan berbagai kebijakan untuk kemajuan madrasah. Suatu hal yang menggembirakan bahwa kebijakan dalam perbaikan pendidikan tersebut, merupakan salah satu modal bagi lembaga-lembaga pendidikan untuk menemukan bentuknya yang ideal sesuai dengan visi, misi lembaga terkait, termasuk lembaga pendidikan madrasah dalam menyelenggarakan pendidikan sesuai dengan kondisi daerah untuk mengembangkan kreatifitas lembaga dalam meningkatkan mutu (kualitas) pelayanannya. Karena melihat kompleksitas dan kemajuan masyarakat sekarang, mengisyaratkan bahwa lembaga pendidikan seharusnya tanggap dan memiliki kemampuan untuk mengakomodir tuntutan perkembangan tersebut dan saatnya pendidikan memberdayakan kondisi lokal daerah dengan segala potensinya. Intinya adalah bagaimana menggugah dan membuka peluang masyarakat lokal untuk berperan serta dalam menentukan arah pendidikan bagi generasi muda sebagai peserta didik.

Madrasah merupakan lembaga pendidikan di Indonesia yang lahir setelah munculnya ide-ide pembaruan pemikiran Islam di Indonesia. Karena itu, unsurunsur pendidikan modern ditemukan di madrasah, seperti sistem klasik, manajemen pendidikan. Mata pelajaran agama dan umum jadi seimbang. Dinamika madrasah saat ini mengantarkan madrasah menjadi sekolah yang berciri khas agama Islam, dan tidak terlepas dari Fungsi dan Tujuan Pendidikan Nasional. Hal ini jelas dinyatakan dalam Undang-Undang RI tentang Sistem Pendidikan Nasional (UU. SPN) Nomor 20 Tahun 2003, pasal III Mengenai Fungsi dan Tujuan Pendidikan Nasional.

"Pendidikan nasional berfungsi mengembangkan kemampuan dan membentuk watak serta peradaban Bangsa yang bermartabat dalam rangka mencerdaskan kehidupan Bangsa, bertujuan untuk berkembangnya potensi peserta didik agar menjadi manusia yang beriman dan bertakwa kepada Tuhan Yang Maha Esa, berakhlak mulia, sehat, berilmu, cakap, kreatif, mandiri, dan menjadi warga negara yang demokratis serta bertanggung jawab". 8

kemajemukan bangsa, Redaksi Sinar Grafika, Undang-Undang Sistem Pendidikan Nasional No. 20 Tahun 2003, (Jakarta: Sinar Grafika; 2003). h. 6 hal yang sama juga melihat perbaikan mutu komponen pendidikan yang dituangkan dalam Bab II Pasal 4 kedudukan guru yaitu sebagai tenaga profesional berfungsi untuk meningkatkan martabat dan peran guru sebagai agen pembelajaran untuk meningkatkan mutu pendidikan nasional, Redaksi Sinar Grafika, Undang-Undang Guru Dan Dosen, (Jakarta : Sinar Grafika; 2008), 6

${ }^{8}$ Redaksi Sinar Grafika, Undang-undang Sistem Pendidikan Nasional No. 20 Tahun 2003 (Jakarta: Sinar Grafika; 2003), 7. 
Terwujudnya fungsi dan dan tujuan pendidikan yang demikian luas cakupannya, maka setiap jenjang, jenis dan jalur pendidikan diupayakan penyelenggaraan secara terpadu, terarah dan secara berkesenambungan dalam berbagai sudut kegiatan kependidikan secara menyeluruh. Diantara kegiatan kependidikan yang dimaksud meliputi kegiatan lembaga pendidikan umum dan lembaga kegiatan agama, baik sebagai lembaga yang sifatnya formal atau informal maupun nonformal.

\section{Konsep Dasar Madrasah dan Jenjang Pendidikan}

Madrasah merupakan isim makan dari "da-ra-sa" yang berarti "tempat duduk untuk belajar"9. Sebutan itu merujuk kepada fungsi utama madrasah dalam kultur Islam, yaitu tempat belajar. Berdasarkan arti di atas sebagian ahli pendidikan Islam menyebutkan bahwa pusat-pusat pendidikan dengan nama madrasah. Jadi pengertian madrasah ialah merupakan suatu lembaga pendidikan yang dibentuk dengan sengaja sebagai pusat berlangsungnya proses pendidikan. ${ }^{10}$ Dilihat dari pengertian ini, maka madrasah berarti merupakan tempat untuk mencerdaskan peserta didik, menghilangkan ketudaktahuan atau memberantas kebodohan mereka, serta melatih keterampilan mereka sesuai dengan bakat, minat dan kemampuannya. Pengetahuan dan keterampilan seseorang akan cepat using selaras dengan percepatan kemajuan iptek dan perkembangan zaman, sehingga madrasah pada dasarnya sebagai wahana untuk mengembangkan kepekaan intelektual dan informasi, serta memperbaharui pengetahuan, sikap dan keterampilan secara berkelanjutan agar tetap up to date dan tidak cepat usang. ${ }^{11}$

Madrasah termasuk lembaga pendidikan Islam yang di dalam kurikulumnya memuat materi pelajaran agama dan materi pelajaran umum, dimana mata pelajaran agama lebih banyak dibandingkan sekolah umum. ${ }^{12}$ Pengertian di atas diperkuat dengan pengertian madrasah dalam Surat Keputusan Bersama ( SKB ) tiga mentri tahun 1975 Bab I Pasal 1 yang menyebutkan bahwa madrasah adalah lembaga pendidikan yang menjadikan mata pelajaran agama Islam sebagai dasar yang diberikan sekurang kurangnya $30 \%$ di samping mata pelajaran umum. ${ }^{13}$ Dalam konteks inilah, terlihat bahwa madrasah merupakan lembaga pendidikan Islam yang menggunakan sistem dan isi sekolah umum

${ }^{9}$ Enung K Rukiati dan Fenti Hikmawati, Sejarah Pendidikan di Indonesia, (Bandung: Pustaka Setia, 2006), 113

${ }^{10}$ Hery Noer Aly, Ilmu Pendidikan Islam (Jakarta: PT. Logos Wacana Ilmu, 1999), 223224.

${ }^{11}$ Muhaimin, Pengembangan Kurikulum Pendidikan Agama Islam (Jakarta: Raja Grafindo Persada, 2005), 184

12 Abudin Nata (editor), Sejarah Pertumbuhan dan Perkembangan Lembaga-lembaga Pendidikan Islam di Indonesia, (Jakarta: PT. Grasindo, 2001), 195

${ }^{13}$ Haidar Putra Daulay, Sejarah Pertumbuhan dan Pembaharuan Pendidikan Islam di Indonesia, (Jakarta: Prenada Media Group, 2009), 102 
sekaligus pesantren. Penggabungan ini terlihat dari unsur pesantren yang lebih banyak mengajarkan agama dan sekolah umum yang mengajarkan juga pelajaran umum.

Pemaparan di atas di dukung oleh peraturan Mentri Agama Nomor 7 tahun 1950, bahwa madrasah mengandung makna: pertama, tempat pendidikan yang diatur sebagai sekolah dan membuat pendidikan dan ilmu pengetahuan agama Islam menjadi pokok pengajarannya. Kedua, pondok dan pesantren yang memberi pendidikan setingkat dengan madrasah. ${ }^{14}$ Jenis dan tingkatan madrasah di Indonesia antara lain: ${ }^{15}$

a. Raudhatul athfal: lembaga pendidikan pra sekolah yang merupakan kebulatan program paling lama 3 tahun sesuai dengan umur anak didik, dengan tiga tingkatan : tingkat A untuk anak didik 3-4 tahun, tingkat B untuk anak didik 45 tahun, dan tingkat $\mathrm{C}$ untuk anak 5-6 tahun.

b. Madrasah ibtidaiyah adalah madrasah rendah atau dasar. ${ }^{16}$

c. Madrasah Tsanawiyah adalah lembaga pendidikan tingkat pertama yang memiliki ciri khusus keislaman sebagai identitasnya, dan bersifat umum bertujuan memberikan bekal kemampuan yang diberikan bagi siswa yang akan melanjutkan pendidikan di sekolah menengah atas atau aliyah

d. Aliyah adalah lembaga pendidikan tingkat atas yang memiliki ciri khas khusus keislaman sebagai identitas yang bersifat umum bertujuan memberikan bekal kemampuan yang diperlukan bagi siswa yang akan memasuki Perguruan Tinggi.

e. Madrasah diniyyah adalah Lembaga Pengajaran Agama Islam secara klasikal yang berfungsi terutama untuk memenuhi hasrat orang tua yang mengingnkan anak anaknya bersekolah di sekolah sekolah umum untuk mendapatkan pendidikan agama Islam yang lebih baik. Madrasah Diniyyah merupakan lembaga pendidikan non formal di bawah pembinaan kementrian agama. Madrasah ini terdiri dari tiga jenjang: Madrasah Diniyyah Awwaliyah, Madrasah Diniyyah Wustha, dan Madrasah diniyyah Ulya.

Menurut Muhaimin, kehadiran madrasah sebagai lembaga pendidikan Islam dilatar belakangi oleh empat hal. Pertama, realisasi dari pembaharuan pendidikan Islam. Kedua, penyempurnaan sistem pendidikan pesantren agar memperoleh kesempatan yang sama dengan pendidikan sekolah umum. Ketiga, keinginan sebagian kalangan santri terhadap model pendidikan Barat. Keempat,

14 Soegarda Poerbakawatja, Pendidikan dalam Alam Indonesia Merdeka, (Jakarta: Gunung Agung, 1970), 221 h. $203-232$

${ }^{15}$ Rochidin Wahab, Sejarah Pendidikan Islam di Indonesia, (Bandung: Alfabeta, 2004),

${ }^{16}$ Haidar Putra Daulay...., 101 
upaya menjembatani antara sistem pendidikan tradisional pesantren dan sistem pendidikan Barat. $^{17}$

\section{Permasalahan Pendidikan Islam Pada Madrasah}

\section{Permasalah Kebijakan pada Madrasah}

Catatan sejarah kegiatan pendidikan Islam pada madrasah, lahir tumbuh dan berkembang bersama dengan kehadiran agama Islam yang bermula dari kegiatan pengajian-pengajian dari rumah ke rumah di bawah bimbingan seorang guru atau kiyai yang dalam perkembangannya menjadi sebuah lembaga pondok pesantren. Berdirinya madrasah karena hasil inisiatif masyarakat setempat, sehingga baik secara perseorangan maupun organisasi segi penyelenggaraannyapun umumnya bernaung dibawah payung organisasi sosial keagamaan seperti NU, Muhammadiyah dan organisasi lokal. Juga ada milik keluarga, milik perorangan atau yayasan. Segi kualitas sangat beragam dari yang sekedarnya hingga yang unggul, namun umumnya bertahan dalam ragam problem. Mulai dari tempat pendidikan yang kurang memadai, tenaga edukasi yang kurang, dana operasional yang tidak dapat membiayai jalannya pendidikan, sampai kualitas guru dan luaran anak didik. Deretan masalah ini membuat posisi madrasah tidak mampu dibeli masyarakat, apalagi untuk menjadi lembaga pendidikan Islam alternatif bagi dunia modern. ${ }^{18}$ bahkan kerap menjadi sekolah pelarian untuk sekedar mendapatkan ijazah formal.

Berbagai ketentuan yang dikeluarkan oleh pemerintah untuk menjawab realitas madrasah yang dimulai dari SKB Tiga Menteri 24 maret 1975 yang tersohor itu, yang menekankan pada persamaan madrasah dengan sekolah-sekolah umum sehingga status dan ijazah madrasah dipersamakan yang dapat diterima oleh semua perguruan Tinggi. PP Nomor 28 Tahun 1990 tentang pendidikan dasar yang menetapkan bahwa madrasah Ibtidaiyyah dan Tsanawiah adalah SD dan SLTP yang berciri khas agama Islam yang diselenggarakan Departemen Agama. ${ }^{19}$ Demikian juga surat Keputusan menteri pendidikan dan kebudayaan Nomor 2/1982 tentang sekolah menengah Umum, menetapkan madrasah Aliyah sebagai SMU berciri khas agama Islam yang diselenggarakan Departemen Agama. Kesemuanya ini merupakan upaya-upaya penyesuaian dalam penyelenggaraan dengan pembinaan yang berdasar kepada ketentuan pokok pikiran yang terdapat dalam Undang-Undang Sistem Pendidikan Nasional. ${ }^{20}$

17 Muhaimin, Pengembangan Kurikulum Pendidikan Agama Islam (Jakarta: Raja Grafindo Persada, 2005), 183

${ }^{18}$ Malik Fadjar....,32 1999), 151

${ }^{19}$ Maksum, Madrasah: Sejarah \& Perkembangannya, (Jakarta, Logos Wacana Ilmu, ${ }^{20}$ Ibid., 155 
Sesuai undang-undang No. 2 Tahun 1989 tentang sistem pendidikan nasional, yang menetapkan pendidikan Islam sebagai sistem pendidikan nasional maka, kedudukan madrasah menjadi sama dengan sekolah-sekolah umum. Hal ini berarti pengelolaan, mutu, kurikulum, pengadaan tenaga dan lain-lain yang meliputi penyelenggaraan pendidikan nasional juga berlaku untuk pengembangan madrasah. Sudah tentu juga pengintegrasian pendidikan Islam yang diselenggarakan di madrasah sebagai sub sistem pendidikan nasional menuntut berbagai penyesuaian dalam arti positif. Dalam kaitan ini madrasah perlu mengkaji kembali hal-hal yang selama ini belum dibenahi sesuai dengan kemajuan jaman. Keadaan ini bukan berarti merupakan kelemahan dari sistem pendidikan madrasah tetapi justru merupakan kekuatan. Masalahnya ialah dengan adanya sistem pendidikan nasional maka berbagai hal perlu distandarisasikan. Peningkatan mutu madrasah, dalam hal ini telah dilakukan usaha penetapan status madrasah, yang diakreditasi dalam Keputusan Menteri Agama nomor 310 tahun 1989 tentang status madrasah dilingkungan direktorat jenderal pembinaan kelembagaan Agama Islam, sedangkan petunjuk pelaksanaannya tertuang dalam keputusan Dirjen Bimbaga Islam Nomor 29/e/1990 tentang pedoman akreditasi madrasah. ${ }^{21}$ Tujuan dilakukannya akreditasi madrasah tersebut adalah mendorong dan meningkatkan mutu pendidikan melalui:

a. Pembaruan kurikulum sesuai dengan ketentuan yang berlaku

b. Tenaga kependidikan yang berkualitas

c. Tersedianya sarana dan prasarana pendidikan yang baik

d. Mendorong terciptanya dan terpeliharanya ketahanan madrasah dan lingkungannya

e. Mendapatkan bahan-bahan bagi perencanaan dalam rangka pembinaan madrasah bersangkutan

f. Melindungi msyarakat dari usaha pendidikan yang kurang bertanggung jawab

g. Memberikan informasi kepada masyarakat tentang mutu pendidikan madrasah

h. Memudahkan pengaturan murid/siswa. ${ }^{22}$

Pelaksanaan akreditasi madrasah meliputi semua aspek penyelenggaraan pendidikan Islam antara lain: kelembagaan, kurikulum, administrasi madrasah, ketenagaan, murid/siswa, sarana prasarana dan situasi madrasah. Berdasarkan akreditasi terhadap komponen-komponen tersebut, ditetapkan jenjang status madrasah tediri dari: status terdaftar, diakui, dan disamakan, status ini berlaku selama lima tahun. ${ }^{23}$ Dengan diberlakukannya Undang-Undang Sistem Pendidikan Nasional baik yang lahir No. 2/1989, disusul dengan UU SPN No.

\footnotetext{
${ }^{21}$ ibid

${ }^{22}$ Husni Rahim....., 111

${ }^{23}$ Mastuhu, Membererdayakan Sistem Pendidikan Islam, (Jakarta: Logos Wacana Ilmu;
} 1999), 111 
20/2003, berimplikasi kepada pemetaan kembali setiap bentuk satuan pendidikan baik lembaga pendidikan yang dikelola oleh pemerintah maupun swasta termasuk madrasah sebagai satuan pendidikan Islam. Hal ini berimplikasi bahwa madrasah sebagai bagian dari sistem pendidikan nasional, bahwa kedudukan madrasah kembali semakin diperkuat, sederajat dengan pendidikan umum yang dikelola oleh Diknas. Pengakuan pemerintah atas madrasah sebagai sub pendidikan nasional mempunyai berbagai konsekuensi, antara lain dimulai suatu pola pembinaan mengikuti satu ukuran yang mengacu kepada sekolah pemerintah. Artinya madrasah mengikuti kurikulum nasional, ikut serta dalam UAN (Ujian Akhir Nasional), dan berbagai peraturan yang diatur oleh Departemen Pendidikan Nasional. $^{24}$

Sementara perkembangan madrasah semakin disoroti baik sebagai wacana maupun implementasi pelaksanaannya ketika lahir UU No. 32 Tahun 2004, Tentang Pemerintahan Daerah dan UU No. 33 tahun 2004, Tentang Perimbangan Keuangan Antara Pemerintah Pusat dan Daerah. Dari ini memberikan kondisi yang cukup berpengaruh kepada pendidikan Islam khususnya madrasah. Oleh karena semangat baru yang timbul dengan otonomi daerah akan memberikan kesempatan kepada seluruh masyarakat untuk berupaya mengelola sendiri kondisi dan kebutuhan daerahnya dalam semua aspek pemgembangannya, namun beberapa kewenangan dalam berbagai bidang masih di tangani oleh pusat, seperti: bidang politik luar negeri, pertahanan keamanan, peradilan serta bidang agama. $^{25}$

Dari sini melahirkan beberapa pendapat yakni: pertama, bahwa pendidikan Islam yang diasuh Departemen Agama ${ }^{26}$ tidak di otonomkan. Hal ini menunjukan pendidikan di Departemen Agama dikategorikan sebagai bagian dari agama. Bukan bagian dari sistem pendidikan nasional. Kedua, pendidikan yang dikelola Departemen Agama adalah bagian sistem pendidikan nasional, karena itu pendidikan di otonomkan. Kenyataan ini membuat madrasah dihadapkan kepada dua pilihan: pertama, Madrasah dalam pengelolaannya tetap diatur secara sentralistik, kedua, madrasah diserahkan pada pemerintah daerah tingkat kabupaten/kota sebagai konsekwensi dari Undang-Undang otonomi daerah dibidang pendidikan. ${ }^{27}$

\footnotetext{
${ }^{24}$ Abdurrahman Shaleh, Madrasah dan Pendidikan Anak Bangsa, (Jakarta: PT. Radja Grafindo Persada; 1998). h. 23

${ }^{25}$ Redaksi Sinar Grafika, Undang-Undang Pemerintahan Daerah 2004 (UU RI No. 32 Th 2004) (Jakarta: Sinar Grafika; 2005), 10-11

${ }^{26}$ Pada saat undang-undang tersebut ditetapkan dinamakan Departemen Agama. Pada saat sekarang Departemen Agama diganti dengan Kementerian Agama

${ }^{27}$ Abd. Rahman Halim, Madrasah Dan Partisipasi Masyarakat, (Makassar, UIN AlauddinPress, 2009), 247
} 
Hal-hal tersebut bukanlah merupakan hal kebetulan tetapi adalah akibat terjadinya perubahan dalam sistem kenegaraan, yang tentu mempengaruhi seluruh sendi-sendi kehidupan berbangsa dan bernegara, tidak terkecuali bidang pendidikan Islam pada madrasah. Karena madrasah sudah termasuk dalam sistem pendidikan nasional, maka untuk memilih alternatif di atas, dalam tulisan ini pemakalah lebih cenderung madrasah dari segi pengelolaannya diotonomikan. Karena dengan otonomi ini merupakan peluang besar dalam memberikan keuntungan terhadap madrasah untuk melakukan pengembangan berupa inovasiinovasi baru bagi penyelenggaraan pendidikan Islam khususnya madrasah. Keuntungan yang di maksud antara lain:

a. Madrasah menjadi kuat kedudukannya sebagai bagian dari Undang-Undang Sistem Pendidikan Nasional (UU SPN), yang implikasinya bagi madrasah memiliki kesejajaran dengan sekolah umum dan mungkin diskriminasi sudah hilang.

b.Para pembina dan kepala sekolah serta guru-guru akan lebih bebas mengembangkan diri dalam pengelolaan madrasah.

c. Suasana akademik akan lebih berkembang karena pengelolaan yang terprogram berkat partisipasi dari semua tenaga yang ada.

d.Elemen masyarakat lebih dapat dimanfaatkan oleh pembina madrasah baik kepala sekolah maupun guru.

e. Pembinaan administrasi akan berimbang dengan pengembangan kreatifitas di bidang akademik.

Meskipun demikian, muncul juga kekhawatiran dari banyak pihak ketika madrasah dilimpahkan ke daerah dan pembinaannya jangan sampai ciri khas madrasah tak dapat dipertahankan justru pembinaannya dilakukan oleh tenaga yang kurang memahami "ruh" dari madrasah itu sendiri, malah mungkin pengelolaan bukan berlatar belakang madrasah. Walaupun demikian sebagai undang-undang otonomi, sudah sepatutnya mendapat sambutan dalam pengimplementasinya. Merupakan suatu kearifan apabila selalu mencarikan alternatif pemecahan yang dapat mendukung keberlangsungan madrasah sebagai institusi pendidikan yang harus berjalan sesuai dengan tingkat perkembangan dan kemajuan masyarakat. Selain dari hal tersebut otonomi daerah juga dapat memberikan kesempatan kepada madrasah berkiprah dalam pengembangan kemitraan secara bebas, dengan lembaga lain terkait dengan penigkatan kualitas atau mutu dalam berbagai aspek.

\section{Permasalahan Kurikulum Pada Madrasah}

Sejak didirikannya, berbagai inovasi pengembangan madrasah telah dilakukan oleh pemerintah dalam hal ini Kementerian Agama, hal ini dimaksudkan untuk meningkatkan mutu out put madrasah. Ketika Mukti Ali 
menjabat sebagai Menteri Agama, ia menawarkan konsep alternatif pengembangan madrasah sebagai mana yang sempat penulis singgung di atas, yakni melalui SKB 3 Menteri, yang berusaha menyejajarkan kualitas madrasah dengan non-madrasah, dengan porsi kurikulum $70 \%$ umum dan $30 \%$ agama. ${ }^{28}$ Pada periode Menteri Agama H. Tarmizi Taher menawarkan konsep madrasah sebagai sekolah umum yang berciri khas agama Islam. ${ }^{29}$ Dilihat dari isu sentralnya, Mukti Ali ingin mendobrak pemahaman masyarakat yang bernada sumbang terhadap eksistensi madrasah, di mana ia selalu didudukkan pada posisi marginal, karena ia hanya berkuat pada masalah keagamaan Islam dan miskin pengetahuan umum, sehingga output-nya pun kurang diperhitungkan oleh masyarakat. Hanya saja ruh SKB 3 menteri tersebut rupanya belum banyak ditangkap oleh para Pembina dan pengelola madrasah itu sendiri. Porsi $70 \%$ pengetahuan umum dan $30 \%$ pengetahuan agama rupanya dipahami secara simbolis-kuantitatif dan bukan subtansial-kualitatif, ${ }^{30}$ sehingga lagi-lagi outputnya menjadi mandul, penguasaan pengetahuan umum masih dangkal dan pengetahuan agamanya pun tidak jauh berbeda.

Untuk mengantisipasi kedangkalan pengetahuan agama dari lulusan madrasah, maka Menteri Agama Munawir Sadzali mencoba menawarkan MAPK (Madrasah Aliyah Program Khusus). Pada MAPK bisa dikatakan bahwa sekitar $70 \%$ dari muatan kurikulumnya merupakan bidang-bidang studi agama. ${ }^{31} \mathrm{Hal}$ ini dimaksudkan untuk menjawab problem kelangkaan ulama dan/atau kelangkaan umat yang mengusai kitab-kitab berbahasa Arab serta ilmu-ilmu keislaman. Lulusan MAPK diharapkan mampu menjawab masalah tersebut, yang sekarang ditetapkan sebagai Madrasah Aliyah Kejuruan (Bidang Keagamaan). Selanjutnya, sebagai akibat dari kemandulan keilmuan yang dimiliki output madrasah, maka Menteri Agama Tarmidzi Taher mencoba menawarkan kebijakan dengan jargon "Madrasah sebagai sekolah umum yang bercirikhas agama Islam", yang muatan kurikulumnya sama dengan sekolah non-madrasah. Kebijakan ini dilanjutkan oleh Menteri Agama berikutnya. Hingga saat ini berbagai permasalahan sekaligus menggerakkan inovasi pengembangan madrasah terus dilakukan. Misalnya adanya yang disebut Madrasah Aliyah Program Keterampilan. Madrasah Aliyah Program keterampilan ini bukan merupakan lembaga pendidikan yang berdiri

\footnotetext{
${ }^{28}$ Muhaimin, Wacana Pengembangan Pendidikan Islam (Cet. II; Surabaya: Pustaka Pelajar, 2004), 175.

${ }^{29}$ Muhaimin, Pengembangan Kurikulum Pendidikan Agama Islam (Jakarta: Raja Grafindo Persada, 2005), 197.

${ }^{30}$ Ibid., 198.

${ }^{31}$ Maksum....,160.
} 
sendiri. Akan tetapi merupakan program pendidikan yang dikembangkan oleh Madrasah Aliyah tertentu seperti madrasah kejuruan.

Selain itu, yang tidak asing lagi kita dengar saat ini adanya Madrasah Model. Madarasah model berfungsi (1) sebagai percontohan bagi madrasah satelit di sekitarnya dalam bidang mutu kelembagaan, kurikulum, proses dan outcome pembelajaran yang optimal; (2) sebagai pusat kegiatan belajar mengajar atau pusat sumber belajar yang inovatif dan memberikan kesempatan kepada madrasah lain memanfaatkan fasilitas yang tersedia bagi peningkatan mutu madrasah di lingkugannya yang tergabung dalam Kelompok Kerja Madrasah (KKM); dan (3) sebagai pusat pemberdayaan yang menumbuhkan sikap mandiri bagi madrasah di lingkungannya.Inovasi pengembangan kurikulum madrasah lainnya adalah inovasi yang diintrodusir oleh pemerintah pusat dalam hal ini Kementerian Agama, sebagai yang tertuang dalam Master Plan Madrasah Terpadu. Yang diinginkan dari konsep madrasah terpadu ini adalah (1) melahirkan keterpaduan kualitas yang merata antara ketiga jejang madrasah yakni MIN, MTSN, dan MAN, sehingga memiliki daya tarik yang sama kuatnya dari masyarakat peminat madrasah; (2) memiliki konsep kurikulum yang terpadu antara ketiga jenjang madrasah, sehingga ketiga jenjang ini merupakan kelanjutan secara terpadu dan utuh; (3) sebagai konsekuensinya agar melahirkan keterpaduan itu maka perlu dibangun manajemen, sutruktur organisasi/kelembagaan, arah pengembangan, dan pendanaan yang mendukung konsep keterpaduan tersebut. Kerangka kurikulum madrasah secara umum untuk mengembangkan kepribadian anak yang dikelola selama ini berdasarkan kebijakan pemerintah mulai MI, MTs dan MA antara lain:

a. Pendidikan pancasila dan kewarganegaran

b. Mata pelajaran PAI antara lain: al-Qur'an Hadits, akidah akhlak, fiqih, SKI dan bahasa arab sebagai penunjang.

c. Mata pelajaran umum antara lain: bahasa Inggris, matematika, pengetahuan alam, pengetahuan sosial, kesenian, pendidikan jasmani dan keterampilan

d. Pembiasaan dan muatan lokal (ditentukan oleh madrasah) ${ }^{32}$

Sebagai bahan perbandingan keberadaan kurikulum pada madrasah awal yang seharusnya menjadi rujukan untuk kurikulum pada madrasah sebagaimana yang telah dilaksanakan oleh madrasah Rahmah al-Yunusiah dalam mempertahankan nuansa kajian keagamaan (tafaqqahu fiddin) antara ain; fiqih, tafsir, tauhid, hikmah tasyri', adab (akhlak), hadits, nahwu, saraf, ilmu bumi, usul fiqih, 'arudh, tarikh Islam, menulis arab, keputrian, pendidikan rumah tangga, bahasa inggris, belanda dan sebagainya. ${ }^{33}$

\footnotetext{
${ }^{32}$ Abdurrahman Shaleh, Madrasah dan Pendidikan Anak Bangsa, (Jakarta, Radja Grafindo Persada, 2004), 201-209

${ }^{33}$ Maksum..., 104
} 


\section{Solusi Permasalahan Madrasah Sebagai Pendidikan Alternatif Umat Islam}

\section{Penguatan Kurikulum Berbasis Integrasi Keilmuan}

Persepsi masyarakat terhadap madrasah di era modern belakangan ini, semakin menjadikan madrasah sebagai lembaga pendidikan yang unik. Di saat ilmu pengetahuan dan teknologi berkembang pesat, dan di saat perdagangan bebas dunia makin mendekati pintu gerbangnya, keberadaan madrasah tampak makin dibutuhkan orang. Untuk mewujudkan harapan semua pihak, madrasah harus melakukan perubahan disemua lini, baik mengenai peningkatan mutu pendidikan yang mencakup kurikulum, materi, metode, sarana pendidikan, dan evaluasi. ${ }^{34}$ Peningkatan kualitas SDM yang mencakup kepala, komite, guru, dan pihak-pihak yang terkait dengan madrasah. Kurikulum tidaklah merupakan hal yang pasti (statis), artinya keberadaan kurikulum harus berubah sesuai dengan perkembangan zaman dan sesuai dengan lingkungan. agar nantinya menghasilkan lulusan yang cerdas dan bermoral. Kurikulum madrasah harus disesuaikan dengan lingkungan, perkembangan zaman, dan kemajuan teknologi karena masyarakat pada umumnya selalu berubah sesuai dengan perubahan zaman. ${ }^{35}$ Untuk itu, diperlukan sebuah kurikulum yang mampu menciptakan aspek lingkungan hidup, pegangan hidup, kebutuhan hidup, dan dinamika kehidupan. Kurikulum yang dimaksud, menurut Muhaimin, dengan kurikulum terintegrasi dikembangkan secara terpadu, dengan menjadikan ajaran dan nilai-nilai Islam sebagai petunjuk dan sumber konsultasi bagi pengembangan berbagai mata pelajaran umum, yang operasionalnya dapat dikembangkan dengan cara mengimplisitkan ajaran dan nilai Islam ke dalam bidang studi IPS, IPA dan sebagainya, sehingga kesan dikotomis tidak terjadi. ${ }^{36}$ Untuk tujuan itu, diperlukan pergeseran paradigma dan karakteristik keilmuan dalam penerapan kurikulum pendidikan madrasah.

Menurut Husni Rahim, ia menyatakan bahwa madrasah sebagai lembaga pendidikan yang bercirikan Islam tidak hanya ciri formal dalam kurikulum saja. Namun, setidaknya ada tiga program utama yang perlu ditetapkan. Pertama, program Mafikib dengan nuansa Islam. Kedua, program pelajaran agama dengan nuansa iptek, dan ketiga, penciptaan suasana keagamaan di madrasah. ${ }^{37}$ Program mafikibb dengan nuansa Islam dimaksudkan untuk menopang reintegrasi antara

\footnotetext{
${ }^{34}$ Sanaky, Hujair AH. Pendidikan Islam Alternatif Upaya Mengembangkan Madrasah (ebook).

${ }^{35}$ Sutrisno, Pendidikan Islam Yang Menghidupkan, Studi Kritis Terhadap Pemikiran Fazlur Rahman, (Yogyakarta: Kota Kembang, 2006), 20

${ }^{36}$ Muhaimin, Pengembangan Kurikulum Pendidikan Agama Islam: di Sekolah, Madrasah dan Perguruan Tinggi, (Jakarta, Rajawali Press, 2012), 209

${ }^{37}$ Program mafikib adalah singkatan untuk mata pelajaran Matematika, Fisika, Kimia, Biologi dan Bahasa Inggeris. Bidang studi mafikibb ini merupakan aspek pendidikan yang dominan dalam peningkatan kemampuan nalar dan analisi siswa. Melalui bidang studi mafikibb siswa akan lebih mudah mengembangkan iptek dengan nuansa Islam. Rahim, Husni. Arah Baru Pendidikan Islam di Indonesia, (Jakarta: Logos Wacana Ilmu, 2001), 41
} 
ilmu-ilmu umum dengan ilmu agama, agar tidak ada lagi dikotomi ilmu. Sedangkan program pelajaran agama dengan iptek merupakan kelanjutan dari mafikibb dengan nuansa Islam. Materi pelajaran di setiap jenjang pendidikan madrasah -MI, Mts, MA- hendaknya berkelanjutan. Ini diharapkan agar nantinya materi pelajaran tidak hanya mengulang-ulang. Menurut A. Malik Fajar, MI sebagai pendidikan tingkat dasar mempunyai peran penting dalam proses pembentukan kepribadian peserta didik, baik bersifat internal, eksternal, dan suprainternal. $^{38}$ Oleh karena itu, lembaga pendidikan dasar (MI) sangat membutuhkan perhatian lebih, baik sistem, materi, manajemen, maupun mutu, agar nantinya kesalahan yang dilimpahkan kepada madrasaah ibtidaiyah tidak terulang lagi.

Sebenarnya, pendidikan di madrasah sendiri sudah mengalami perubahan besar-besaran. Tetapi, karena perubahan masyarakat lebih cepat, maka dunia pendidikan bagaikan jalan ditempat. Perbaikan kurikulum, peningkatan mutu guru dan pembinaannya, sebenarnya bisa dibilang dapat menjawab kebutuhan masyarakat dan pembangunan. Akan tetapi, usaha yang baik itu kurang dibarengi dengan kesungguhan untuk memperbaiki perangkat pendukungnya seperti guru, sarana prasarana, serta kebijakan administratif. Komponen-komponen yang diperlukan tidak dapat berjalan bersamaan, sehingga terjadi kepincangan dan kegagalan dalam perbaikan.

Permasalahan yang dihadapi oleh madrasah bukanlah tantangan semata, tetapi itu adalah jalan untuk merumuskan madrasah ke depan dengan matang. Ketika menelaah keberadaan kurikulum pada madrasah, Muhaimin menawarkan konsep pendidikan Islam pada madrasah terutama terhadap kurikulum yang diberlakukan ke depan yaitu dengan konsep to return to god though religion (kembali kepada Tuhan melalui agama). ${ }^{39}$ Ia bermaksud ketika melihat ke belakang dengan berbagai dinamika pendidikan Islam pada madrasah sedikit banyak mengalami kelemahan baik keterbatasan pengetahuan dan sifat egoisme atau ingin mendahulukan kepentingan personal dan kelompok. Karena itu yang mengatur urusan manusia adalah Allah SWT maka harus mengikuti aturan-aturan dan petunjuk Allah SWT yang bisa dijangkau oleh akal manusia, peraturan itulah yang kemudian dinamai dengan agama. Peraturan tersebut jika dikaitkan dengan kurikulum maka penawaran kurukulum pada madrasah adalah semagaimana ajaran agama menawarkan semua pokok-pokok ajaran agama yang harus disisipkan pada semua mata pelajaran.

\footnotetext{
${ }^{38}$ Fajar. A. Malik. Madrasah dan Tantangan Modernitas, (Bandung: Mizan, 1998), h. 35

${ }^{39}$ Muhaimin...., 199
} 
Karena itu, menjadikan madrasah sebagai wahana untuk membina ruh $^{40}$ dan praktek hidup keislaman, terutama dalam mengantisipasi peradaban global, adalah merupakan tawaran yang selalu actual. Walaupun masalah actual atau tidaknya diserahkan kepada penangung jawab, pengelola madrasah dan Pembina madrasah untuk dijabarkan, diaktualkan untuk menjadikan madrasah sebagai wahana untuk membina ruh dan praktik hidup keislaman itu, tidak saja symbolis tetapi sampai menyentuh pada dimensi substansial. Melalui pemahaman itu diharapkan madrasah dapat melahirkan lulusan yang memahami dan bahkan menguasai iptek, terampil dan sekaligus siap hidup dan bekerja dimasyarakat dalam pancaran dan kendali ajaran dan nilai-nilai Islam. ${ }^{41}$

Begitu juga pihak-pihak yang terkait harus bekerja sama dalam menjalankan roda pendidikan Islam pada madrasah agar berjalan beriringan sesuai dengan tujuan pendidikan, tidak sepihak, dengan tidak terjadi kepincangan dalam mengembangkan madrasah. Tidak terkecuali mengontrol para pendidik karena mereka merupakan pihak yang secara langsung berinteraksi dengan anak didik. Dengan demikian, harapan untuk membantu pemerintah dalam mengentaskan kebodohan dan kemiskinan dapat terwujud. Pendidikan Islam khususnya di madrasah akan berhasil sesuai dengan harapan semua pihak dan berkembang sejajar dengan pendidikan pada umumnya, bahkan lembaga pendidikan madrasah mampu menghasilkan siswa yang berkualitas yang nantinya sebagai ujung tombak dalam kemajuan bangsa.

\section{Arah Kebijakan Pengembangan Madrasah}

Dalam pengembangan pendidikan Islam khususnya pada madrasah tidak perlu melihat madrasah sebagai pendidikan kelas dua. Tindakan dan langkah nyata justru jauh lebih berarti dalam mengatasi masalah akut yang dialami madrasah-madrasah selama ini. Apapun kemajuan madrasah yang dikehendaki harus melalui proses kebijakan pengembangan. Dalam hal ini setidaknya perlu mengakomodasikan tiga kepentingan utama. Pertama, bagaimana kebijakan tersebut masih memberi ruang tumbuh yang wajar bagi aspirasi utama umat Islam. Yakni menjadikan madrasah sebagai wahana untuk membina ruh atau praktik hidup keislaman. Dalam hal ini madrasah dituntut dapat melahirkan golongan terpelajar (leaner society) yang bisa menjalankan peran tafaqquh fid-diin.

${ }^{40}$ Abdul Hamid al-Balali mengistilahkan madrasah sebagai wahana untuk membina ruh dengan istilah madrasah pendidikan jiwa. Pendidikan jiwa dalam arti pendidikan berorientasi dengan mengedepankan pada berbagai macam muatan materi yag kesemuanya berasal dari alQur'an dan hadits. Lulusan pendidikan madrasah pendidikan jiwa memiliki jejak yang tidak terputus, mulai dari masa shahabat nabi, generasi thabiin demikian seterusnya pada generasi kejayaan Islam selanjutnya sampai sekarang. Abdul Hamid Al-Balali, Manhajut Thabiin Fi Tarbiyatun Nufus, diterjemahkan menjadi Madrasah Pendidikan Jiwa, (Jakarta, Gema Insani Press, 2003), 12

${ }^{41}$ Muhaimin...,208 
Kedua, bagaimana kebijakan pengembangan itu memperjelas dan memperkukuh keberadaan madrasah sebagai ajang membina warga negara yang cerdas, berpengetahuan, berkepribadian serta produktif, sederajat dengan sekolah. Porsi dari kebijakan ini agar program kegiatan pendidikan madrasah sanggup mengantarkan peserta didik memiliki penguasaan ilmu pengetahuan umum dan mengembangkan keterampilan kerja. Dan ketiga, bagaimana kebijakan pengembangan madrasah dapat merespon tuntutan masa depan. Karena itulah madrasah harus diarahkan kepada lembaga yang memiliki kesanggupan untuk melahirkan sumber daya manusia yang memiliki kesiapan globalisasi dan era industrialisasi dengan tetap mempertahankan kulturnya sebagai institusi yang memiliki kepentingan keagamaan.

Pelaksanaan pendidikan selama ini banyak diwarnai dengan pendekatan sarwa negara, dimasa yang akan datang harus berorientasi pada aspirasi masyarakat, pendidikan harus mengenali siapa pelanggannya dan dari pengenalan ini pendidikan harus memahami apa aspirasi dan apa kebutuhan setelah mengetahui aspirasi dan kebutuhan mereka, ditentukan sistem pendidikan, seperti kurikulum dan persyaratan pengajarannya. Dari berbagai ulasan di atas, sudah saatnya direkomendasikan munculnya "kebijakan berbasis masyarakat", dengan tujuan bagaimana kebijakan pendidikan itu mendapat respon positif dari masyarakat secara umum. ${ }^{42}$

Oleh karena itu, madrasah harus mendesain ulang model pendidikan Islam dari model klasik ke model sesuai dengan kebutuhan umat Islam yang berkualitas dan bermutu. Menurut Hujair AH. Sanaky, setidaknya ada lima hal yang harus didesain, ${ }^{43}$ yaitu: pertama, dengan merumuskan visi ${ }^{44}$ dan misi serta tujuan yang jelas. Kedua, kurikulum dan materi pembelajaran diorientasikan pada kebutuhan peserta didik dan kebutuhan masyarakat untuk dapat menjawab tantangan perubahan. Ketiga, metode pembelajaran diorientasikan pada upaya pemecahan kasus (problem solving) dan bukan dominasi ceramah. Keempat, manajemen pendidikan diorientasi pada manajemen berbasis sekolah. Kelima, organisasi dan sumber daya guru yang memiliki kompetensi dan profesional dalam bidangnya masing-masing. ${ }^{45}$ Maka pendidikan Islam akan mampu bersaing dengan mampu

\footnotetext{
${ }^{42}$ Abd. Rahman Halim, Madrasah Dan Partisipasi Masyarakat, (Makassar, UIN AlauddinPress, 2009), 83

${ }^{43}$ Ibid.

${ }^{44}$ Visi pendidikan madrasah sebagaimana yang dikemukakan oleh H. A. Mukti Ali menempatkan arah dan orientasi pendidikan Islam berpusat pada masa depan terutama pada pengembangan sumber daya manusia sebagai penanggung jawab dalam pelaksanaan pendidikan Islam. Ia menempatkan bahwa sumber daya manusia sebagai panglima dalam mendesain keberlangsungan pendidikan Islam dengan menempatkan bab khusus tentang visi pendidikan dalam perspektif sumber daya manusia. H. A. Malik Fajar...., 38

${ }^{45}$ Sanaky, Hujair AH. Pendidikan Islam Alternatif Upaya Mengembangkan Madrasah (ebook).
} 
mempersiapkan dan melahirkan pemimpin-pemimpin yang tangguh, berkualitas dan berkaliber dunia dalam bidangnya sehingga mampu menjawab persoalanpersoalan aktual atau kontemporer sesuai dengan kebutuhan perubahan zaman.

Madrasah mestinya tidak perlu terpengaruh oleh lembaga pendidikan lain yang bermunculan dengan berbagai label unggulannya. Hal ini dikarenakan pada umumnya sebenarnya justru mengadopsi sistem model madrasah secara tidak langsung. Untuk itu yang perlu dikedepankan adalah bagaimana membuat manajemen kelambagaan yang bagus kemudian mengkomunikasikannya kepada masyarakat. Dengan melihat kelebihan madrasah sebagai pendidikan alternative bagi umat Islam bahwa madrasah perlu dikembangkan kearah peningkatan kualitas madrasah. Hal ini sebagaimana yang dikemukakan oleh Muhaimin yang perrlu dijawab oleh pemangku kepentingan pada madrasah yaitu:

a. Bagaimana menjadikan madrasah sebagai wahana untuk membina ruh atau praktek hidup keislaman.

b. Bagaimana memperkokoh keberadaan madrasah sehingga sederajat dengan system sekolah

c. Bagaimana madrasah mampu merespon tuntutan masa depan guna mengantisipasi perkembangan iptek dan era globalisasi. ${ }^{46}$

Dengan demikian, kualitas madrasah terletak pada dijadikannya pandangan hidup dan keterampilan hidup yang berspektif Islam sebagai core (inti) pelaksanaan pendidikan pada madrasah. Demikian, di madrasah perlu dilakukan supaya spiritualisasi pendidikan atau upaya menginternalisasikan nilai-nilai spirit agama melalui proses pendidikan ke dalam seluruh aspek pendidikan madrasah. Hal ini dimaksudkan untuk memadukan nilai-nilai sains dan teknologi serta seni dengan keyakinan dan keshalehan dalam diri peserta didik. Sehingga suasana pendidikan pada madrasah menghendaki kemantapan keimanan, kreatifitas (amal shaleh) warga madrasah dan peserta didik, dari semenjak masuk, proses pelaksanaan sampai kepada ketika keluar (lulusan) merada pada nilai-nilai ketakwaan. Sebagaimana diisyaratkan dalam al-Qur'an surah al-Hasyar ayat 18, sebagai berikut:

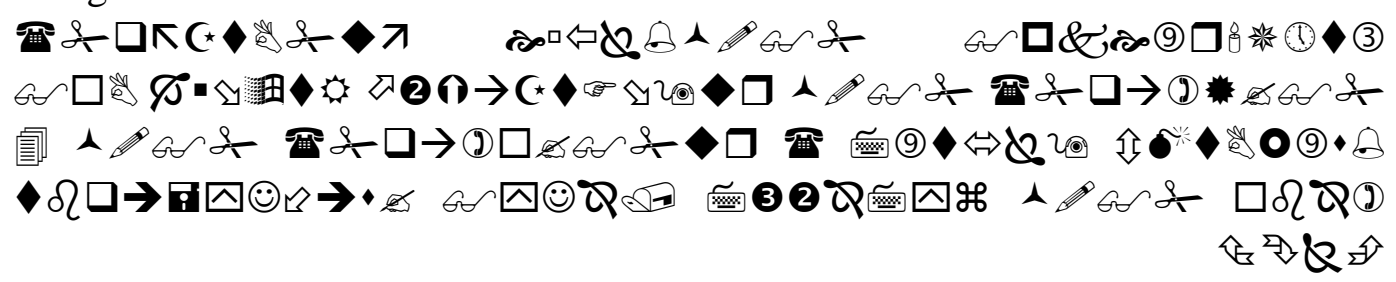

"Hai orang-orang yang beriman, bertakwalah kepada Allah dan hendaklah Setiap diri memperhatikan apa yang telah diperbuatnya untuk hari esok (akhirat); dan bertakwalah kepada Allah, Sesungguhnya Allah Maha mengetahui apa yang kamu kerjakan"

\footnotetext{
${ }^{46}$ Muhaimin...., 200
} 


\section{Analisis Kritis Terhadap Permaslahan Madrasah dalam Pendidik Islam}

Tidak berlebihan, jika terdapat satu ungkapan yang menyatakan bahwa pendidikan Islam Indonesia telah memberikan warna dan kontribusi terhadap sistem pendidikan nasional. Sjafri Sairin ${ }^{47}$ menegaskan bahwa sistem pendidikan Islam di Indonesia dari masa penjajahan sampai masa kini merupakan bagian tak terpisahkan dari sistem pendidikan nasional. Terjadinya dinamika perubahan dalam sistem pendidikan Islam sejak masa penjajahan hingga kini, menunjukkan indikasi yang kuat bahwa pendidikan Islam dapat menyesuaikan diri dan beradaptasi dengan perkembangan masyarakat. Perubahan tersebut juga menggambarkan bahwa komunitas muslim dapat melakukan pembauran dalam sistem pendidikan Islam yang mereka geluti dengan dinamika yang sedang berkembang di masyarakat saat ini. Walaupun demikian, terdapat hal yang menarik dicermati terkait bagaimana lembagalembaga pendidikan Islam menghadapi tantangan dan dinamika perubahan. Menurut Azyumardi Azra ${ }^{48}$ para eksponen lembaga-lembaga pendidikan Islam terlihat tidak terlalu tergesa-gesa mentranformasikan perubahan kelembagaan Islam, tetapi cenderung mempertahankan kebijaksanaan yang penuh kehati-hatian, mereka menerima pembaharuan atau modernisasi secara terbatas tanpa harus melakukan perubahan sistem pendidikan Islam secara menyeluruh. Karena sesungguhnya praksis pendidikan di masing-masing lembaga pendidikan Islam memiliki keunikan dan ciri khas, yang secara sosiologis dan filosofis tentu berbeda-beda sesuai dengan tradisi dan disiplin keilmuan yang dikembangkan para pendirinya. Lebij lanjut, dalam pandangan Azyumardi Azra, menekankan bahwa perubahan bentuk dan isi pendidikan Islam di Indonesia tidak dapat melepaskan diri dari tuntutan perubahan zaman. Menurutnya, lembaga-lembaga pendidikan Islam harus memiliki visi keislaman, kemoderenan, keknian, masa depan dan kemanusian agar compatible dengan perkembangan. ${ }^{49}$

Mencermati kondisi yang dihadapi oleh madarasah di atas, pemikiran kembali tujuan dan fungsi lembaga-lembaga pendidikan Islam. Artinya lembagalembaga pendidikan tidak hanya berorientasi atau memenuhi keinginan kepentingan akhirat saja dengan mengajarkan keterampilan beribadah saja. Hal itupun, masih dirasakan apabila pendidikan Islam dipandang dari dimensi ritual masih jauh dalam memberikan pengayaan spritual, etika dan moral. Memang diakui, bahwa peserta didik secara verbal kognitif dapat memahami ajaran Islam dan terampil dalam melaksanakannya (psikomotorik), tetapi kurang menghayati (afektif) kedalaman maknanya. Oleh karena itu, lembaga-lembaga pendidikan

\footnotetext{
${ }^{47}$ Sjafri Sairin, Perubahan Sosial Masyarakat Indonesia: Prespektif Antropologi (Yogyakarta: Pustaka Pelajar, 2002), 35.

${ }^{48}$ Azyumardi Azra, Pesantren: Kontinuitas dan Perubahan dalam Nurcholish Madjid, Bilik-Bilik Pesantren: Sebuah Potret Perjalanan (Jakarta: Paramadina, 1997), xvi.

${ }^{49}$ Azyumardi Azra...., 40
} 
Islam khususnya madrasah harus menjadikan pendidikannya tersebut sebagai tempat untuk mempelajari ilmu-ilmu agama (spritual ilahiyah), ilmu pengetahuan, teknologi, keterampilan atau kemahiran, seni dan budaya serta etika dan moral ilahiyah.

Selain persoalan tersebut, madrasah sekarang ini juga dihadapkan pada persoalan-persoalan yang cukup kompleks, yakni persoalan manajemen, reformasi dan globalisasi menuju masyarakat Indonesia baru. Tantangan yang dihadapi sekarang adalah bagaimana upaya untuk membangun paradigma baru pendidikan Islam, visi, misi, dan tujuan, yang didukung dengan sistem kurikulum atau materi pendidikan, manajemen dan organisasi, metode pembelajaran untuk dapat mempersiapkan manusia yang berkualitas, bermoral tinggi dalam menghadapi perubahan masyarakat global yang begitu cepat, sehingga produk pendidikan Islam tidak hanya melayani dunia modern, tetapi mempunyai pasar baru atau mampu bersaing secara kompetetif dan proaktif dalam dunia masyarakat modern, global dan informasi. Perubahan yang perlu dilakukan pendidikan Islam, yaitu: pertama, Membangun sistem pendidikan Islam yang mampu mengembangkan sumber daya manusia yang berkualitas agar mampu mengantisipasi kemajuan iptek untuk menghadapi tantangan dunia global menuju masyarakat Indonesia baru yang dilandasi dengan nilai-nilai ilahiyah, kemanusia (insaniyah), dan masyarakat, serta budaya. Kedua, Menata manajemen pendidikan Islam dengan berorientasi pada manajemen berbasis sekolah agar mampu menyerap aspirasi masyarakat, dapat mendayagunakan potensi masyarakat, dan daerah (otonomi daerah) dalam rangka penyelenggaraan pendidikan Islam yang berkualitas dan ketiga, meningkatkan demokratisasi penyelenggaraan madrasah secara berkelanjutan dalam upaya memenuhi kebutuhan masyarakat agar dapat menggali serta mendayagunakan potensi masyarakat.

Dari uraian di atas, menegaskan bahwa madrasah harus mendisain modelmodel pendidikan alternatif yang sesuai dengan kebutuhan perkembangan sekarang ini. Muncul pertanyaan model-model pendidikan Islam yang bagaimana? Yang diharapkan dapat menghadapi dan menjawan tantangan perubahan yang terjadi dalam kehidupan masyarakat baik sosial maupun kultural menuju madrasah ideal. Untuk menjawab pertanyaan ini, meminjam prinsip hakekat pendidikan Islam yang digunakan Hasim Amir sebagaimana dikutip oleh A. Malik Fajar, mengemukakan bahwa pendidikan Islam termasuk madrasah adalah pendidikan yang idealistik, yakni pendidikan yang integralistik, humanistik, pragmatik dan berakar pada budaya kuat. ${ }^{50}$ Tawaran tawaran tersebut, dapat digunakan sebagai konsep pendidikan pada madrasah dalam mamajukan dan mempersiapkan madrasah menjadi pendidikan yang ideal untuk umat Islam, yaitu: Pendidikan integralistik, merupakan model pendidikan yang diorientasikan pada

\footnotetext{
${ }^{50}$ A. Malik Fadjar, Reorientasi Pendidikan Islam ...,. 37
} 
komponen-komponen kehidupan yang meliputi: Pendidikan yang berorientasi pada Rabbaniyah (Ketuhanan), insaniyah (kemanusiaan) dan alamiyah (alam pada umumnya), sebagai suatu yang integralistik bagi perwujudan kehidupan yang baik dan untuk mewujudkan rahmatan lil 'alamin, serta pendidikan yang menganggap manusia sebagai sebuah pribadi jasmani-rohani, intelektual, perasaan dan individual-sosial.

\section{Penutup}

Dari pembahasan di atas dapat ditarik sebuah kesimpulan bahwa, kondisi madrasah pada saat ini masih mengalami ketertinggalan jika dibandingkan dengan sekolah-sekolah umum. Bahkan madrasah kian terpinggirkan dengan semakin banyaknya sekolah umum yang bercirikan Islam berkembang secara lebih cepat. Sebuah hal yang sangat ironis manakala model pendidikan madrasah yang sudah cukup ideal tersebut tidak dapat dikembangkan dan diberdayakan menjadi sebuah desain madrasah yang unggul, tetapi justru diadopsi oleh sekolah umum dan dapat dikembangkan menjadi sekolah yang bermutu. Untuk itu madrasah semestinya tidak perlu terpengaruh untuk mengikuti pola pengembangan sekolah umum yang dianggap lebih baik, sebaliknya madrasah justru perlu mempertahankan karakteristiknya dan mengembangkannya. Dalam hal ini, yang dibutuhkan madrasah sebenarnya adalah penguatan dan pengembangan kelembagaan, penataan kurikulum yang substansial, peningkatan kualitas SDM, dan mengembalikan ruh madrasah sebagai sekolah berbasis masyarakat dan berkarakteristik keagamaan yang kuat. Dengan demikian madrasah tidak hanya akan mampu bersaing dengan sekolah umum yang bercirikan Islam, tetapi justru akan menjadi sekolah Islam yang memiliki berkualitas dengan penguasaan pelajaran umum yang sama.

Sesuai dengan jiwa desentralisasi yang menyerap aspirasi dan partisipasai masyarakat dalam pengembangan dan peningkatan kualitas pendidikan, masyarakat dituntut untuk memiliki kepedulian yang tinggi memperhatikan lembaga pendidikan yang berada di lingkungan setempat. Hal ini dapat menumbuhkan sikap kepemilikan yang tinggi dengan memberikan kontribusi baik dalam bidang material, kontrol manajemen, pembinaan, serta bentuk partisipasi lain dalam rangka meningkatkan eksistensi madrasah yang selanjutnya menjadi kebanggaan lingkungan setempat. Madrasah sebagai lembaga pendidikan Islam yang hidup dari, oleh dan untuk masyarakat tetunya mampu memberikan pengaruh yang cukup besar dalam menciptakan generasi Islam dan semangat kajian keislaman dengan pola manajemen berdasarkan petunjuk dan aturan dalam al-Qur'an dan hadits dalam semua aspek pendidikan madrasah. 


\section{DAFTAR PUSTAKA}

Abudin Nata (editor). Sejarah Pertumbuhan dan Perkembangan Lembagalembaga Pendidikan Islam di Indonesia. Jakarta: PT. Grasindo, 2001.

Al-Balali, Abdul Hamid. Manhajut Thabiin Fi Tarbiyatun Nufus, diterjemahkan menjadi Madrasah Pendidikan Jiwa. Jakarta, Gema Insani Press, 2003.

Bastian, Aulia Reza. Reformasi Pendidikan: Langkah-Langkah Pembaruan Pendidikan Dalam Rangka Desentralisasi Pendidikan Indonesia. Yogyakarta: Lappera; 2002.

Azra, Azyumardi. Pesantren: Kontinuitas dan Perubahan dalam Nurcholish Madjid, Bilik-Bilik Pesantren: Sebuah Potret Perjalanan. Jakarta: Paramadina, 1997.

Enung K Rukiati dan Fenti Hikmawati. Sejarah Pendidikan di Indonesia. Bandung: Pustaka Setia, 2006.

Fadjar, A. Malik, Visi Pembaharuan Pendidikan Islam. Jakarta: LP3ES; 1998. . Madrasah dan Tantangan Modernitas. Bandung: Mizan, 1998.

Fathoni, M. Khalid. Pendidikan Islam Dalam Paradigma Baru Pendidikan Nasional. Bogor: Regina; 2005.

Muhaimin. Wacana Pengembangan Pendidikan Islam. Cet. II; Surabaya: Pustaka Pelajar, 2004.

Muhaimin. Pengembangan Kurikulum Pendidikan Agama Islam. Jakarta: Raja Grafindo Persada, 2005.

Maksum. Madrasah: Sejarah \& Perkembangannya. Jakarta, Logos Wacana Ilmu, 1999.

Mastuhu, Membererdayakan Sistem Pendidikan Islam. Jakarta: Logos Wacana Ilmu; 1999.

Mochtar, Affandi. Membedah Diskursus Pendidikan Islam (Ciputat: Kalimah, 2001.

Noer Aly, Hery. Ilmu Pendidikan Islam. Jakarta: PT. Logos Wacana Ilmu, 1999.

Shaleh, Abdurrahman. Madrasah dan Pendidikan Anak Bangsa, (Jakarta: PT. Radja Grafindo Persada; 1998.

Putra Daulay, Haidar. Sejarah Pertumbuhan dan Pembaharuan Pendidikan Islam di Indonesia. Jakarta: Prenada Media Group, 2009.

Redaksi Sinar Grafika. Undang-Undang RI Nomor 22 Tahun 1999 Tentang Pemerintahan Daerah. Jakarta: Sinar Grafika; 1999.

Redaksi Sinar Grafika, Undang-Undang Sistem Pendidikan Nasional No. 20 Tahun 2003. Jakarta: Sinar Grafika; 2003.

Redaksi Sinar Grafika. Undang-Undang Guru Dan Dosen. Jakarta : Sinar Grafika; 2008.

Rosyada, Dede. Paradigma Pendidikan Demokratis: Sebuah Model Pelibatan Masyarakat Dalam Penyelenggaraan Pendidikan, (Cet. III, Jakarta: Kencana Prenada Media Group; 2009). 
Rahim, Husni. Arah Baru Pendidikan Islam di Indonesia, Jakarta: Logos Wacana Ilmu, 2001.

Sanaky, Hujair AH. Pendidikan Islam Alternatif Upaya Mengembangkan Madrasah (ebook).

Sutrisno. Pendidikan Islam Yang Menghidupkan, Studi Kritis Terhadap Pemikiran Fazlur Rahman. Yogyakarta: Kota Kembang, 2006.

Soegarda, Poerbakawatja. Pendidikan dalam Alam Indonesia Merdeka. Jakarta: Gunung Agung, 1970.

Sairin, Sjafri. Perubahan Sosial Masyarakat Indonesia: Prespektif Antropologi. Yogyakarta: Pustaka Pelajar, 2002.

Wahab, Rochidin. Sejarah Pendidikan Islam di Indonesia. Bandung: Alfabeta, 2004.

Zuhairini, Dkk. Sejarah Pendidikan Islam. Cet. 8, Jakarta: PT. Bumi Aksara Bekerjasama Dengan Direktorat Jenderal Pembinaan Kelembagaan Agama Islam Departemen Agama; 2006. 